How to cite this article:

Che-Adam, Noriah., Lode, Nor Asma., \& Abd-Mutalib, Hafizah. (2019). The influence of board of directors' characteristics on the environmental disclosure among Malaysian companies. Malaysian Management Journal, Vol. 23(December), 1-25.

\title{
THE INFLUENCE OF BOARD OF DIRECTORS' CHARACTERISTICS ON THE ENVIRONMENTAL DISCLOSURE AMONG MALAYSIAN COMPANIES
}

\author{
NORIAH CHE-ADAM* \\ NOR ASMA LODE \\ HAFIZAH ABD-MUTALIB \\ Tunku Puteri Safinaz School of Accountancy \\ Universiti Utara Malaysia \\ *Corresponding author: noriah@uum.edu.my
}

\begin{abstract}
The environmental activities conducted by companies have been scrutinised by the public due to the huge environmental problems faced by many people across the world. These activities are corporate social activities included in the corporate social responsibility (CSR) framework by Bursa Malaysia that informs the public regarding the social and environmental activities implemented by Malaysian companies. Data from 353 companies of various types in Malaysia revealed that the information about effective usage of energy and resources is the most disclosed item by Malaysian companies, followed by the waste management and disposal, and reusing and recycling information. The least disclosed item by Malaysian companies is prevention and reparation program. In addition, the regression results showed that the higher proportion of non-executive directors could increase the disclosure of environmental information. The results prove that the non-executive directors have played their role to increase the companies' legitimacy by encouraging the management of companies to provide more environmental information. Hence, this study provides significant contribution for the supervisory bodies and policy makers in developing guidelines for Malaysian companies
\end{abstract}


concerning environmental issues through environmental disclosures in their annual reports.

Keywords: Corporate governance, Environmental disclosure, Corporate social responsibility (CSR), Non-executive directors, Malaysia.

\section{Introduction}

Since the past three decades, environmental issues such as increasing damage caused by pollution and depletion of resources have raised the attention of the public. Several efforts had been made to improve oil related equipment but the volume of operational oil spill amounted to 0.9 thousand tons for the year 2013 in Nigeria (Shell, 2014). This oil spill has given a significant impact to the environment as it can reduce the quality of soil and groundwater in the affected areas. The government needs to spend a lot of money and time to clean-up the oil spill areas and do a restoration of the biodiversity to ensure the oil spill sites can continue to provide a quality of life not only for human beings but also for all the flora and fauna. In Malaysia, the environmental problem has been an unresolved issue for quite some time. In 2014, an illegal logging was one of the factors that might have caused the 'yellow flood' in Kelantan. In the following year, pollution of water in Pahang was due to the bauxite residual from the unrestrained bauxite mining which had contaminated the environment to the atmosphere (Shah, 2015).

In Malaysia, environmental reporting practices are not compulsory under the Malaysian Companies Act 2016 and Malaysian Accounting Standard Board (MASB). However, in 2007, the Listing Requirement of Bursa Malaysia under item 29 Appendix 9C of Chapter 9 Continuing Operation requires public listed companies in Malaysia to disclose the information related to the corporate social activities. Environmental activities are one of the corporate social activities included in the Corporate Social Responsibility (CSR) framework by Bursa Malaysia (Bursa Malaysia, 2010). The purpose of this requirement is to inform the public regarding the social and environmental activities, to improve the level of social and environmental activities and reporting which could be comparable to the international best practice. In 2015, Bursa Malaysia published the Sustainable Reporting Guide to assist Malaysian companies to prepare social and environmental information in their annual report. This guideline consists of case studies and examples of the social and environmental disclosures that can be used by Malaysian 
companies to present their sustainable activities to users (Bursa Malaysia, 2015). Later in 2018, Bursa Malaysia published the second edition of Sustainable Reporting Guide after taking valuable comments from the users. This new edition has more current case studies and examples with additional guidance for companies that intend to seek the assurance for their sustainable reporting (Bursa Malaysia, 2018).

In addition, the Securities Commission Malaysia has released a revised version of the Malaysian Code on Corporate Governance (MCCG) 2012 document to promote a good corporate governance and business culture. This MCCG highlights the importance of good corporate governance to ensure the companies run their business based on ethical standard and provide a timely and value added information to their stakeholders. The release of a new version of MCCG could provide more reporting of the environmental activities as this code encourages the transparency and disclosure to assist the companies' stakeholder to make a decision (Securities Commission, 2012).

The disclosure of environmental information has been the subject of substantial academic research in the past decades. Some studies find that disclosures of social and environmental information have been increased and related to certain internal and external companies' attributes (Trotmen, 1979; Gray, Kouhy \& Lavers, 1995; Hacktson \& Milne, 1996; Halme \& Huse, 1997; Cormier \& Magnan, 1999; Mobus, 2005; Moerman \& Laan, 2005; Salama, Dixon \& Habbash, 2012; Rupley, Brown \& Marshall, 2012). However, most of these studies focus on the experience of companies in developed countries, mainly in Europe and United States. Empirical evidences from developing countries are much less and mainly concentrate on the trend of social responsibilities reporting and do not specifically focus on the environmental reporting. Furthermore, the findings associated to factors that influence the companies to disclose the environmental information may be different from the studies that examine the environmental disclosure separately from the corporate social disclosures.

In a similar vein, the problem related to the environment is still an issue (i.e., increased in air and river pollution and illegal lodging) which affects to the quality of life for current and future generations given that many steps have been made by Malaysian government to educate and encourage Malaysian companies to protect the environment. Previous studies (Bursa Malaysia, 2008; Iatridis, 2013) show that Malaysian companies are not transparent to the community regarding their social and environmental activities. Hence, Malaysian citizens are looking forward to see how the public companies run their business activities without harming the environment. In line with the above efforts, this study investigates the current status of environmental 
reporting in the annual report among Malaysian listed companies and the determinants of environmental disclosure.

Hence, the present study attempts to fill the gap by examining the current level of environmental disclosure made by Malaysian Companies in their annual reports after the listing requirement of the Bursa Malaysia and the release of MCCG 2012. Principle 7 of this code states that companies should establish corporate disclosure policies and procedures to ensure comprehensive, accurate and timely disclosures. As a result, this principle is about the duty of the board to ensure companies provide comprehensive disclosure of information in a timely basis (Securities Commission, 2012). This study also examines whether corporate governance variable (i.e., board of director characteristics) could influence the quality of environmental disclosure in their annual reports.

\section{Literature Review}

\section{Environmental Disclosure}

Environmental disclosure is defined as "the disclosure by an entity of environmentally related data, verified or not, regarding environmental risks, environmental impacts, policies, strategies, targets, costs, liabilities or environmental performance to those who have an interest in such information, as an aid to enriching their relationship with reporting entity" (ACCA, 2003). Disclosure in the annual reports is one of the mediums to communicate the information which can explain the effect of the organization's operation and products to the environment. In addition, the disclosure can show the commitment of the organisation in reducing pollution, resource depletion, waste and increasing the product quality and safety.

Although preparing the environmental reporting will incur cost and time, but there are many benefits that can be gained from this reporting; for instance, it will increase the number of customers and suppliers who share the same values with the organisation. The greater the transparency of environmental information the greater the confidence and trust between corporation and stakeholder that can further strengthen their relationships. It can also decrease corporate risk and potential liability through reviewing the type of environmental risk that has been ignored by the corporation in the previous accounting periods. However, if there is a lack of environmental reporting, it will increase the indirect costs related to the poor environmental profile compared to the competitors. The companies will also lose all the above benefits. 
Most studies on the environmental reporting are part of the corporate social responsibility reporting. Among the earliest study on corporate social reporting was by Trotman (1979) who found that social reporting in Australia had increased from six percent in 1967 to 35 percent in 1977. Hackson and Milne (1996) investigated the corporate social disclosure in 50 largest companies listed on the New Zealand Stock Exchange as of 31 December 1992. Their study shows that 83 percent of the sample companies make at least one type of social disclosure. Meanwhile, Salama et al. (2012) revealed that 80 percent of companies in United Kingdom disclose the environmental information in their annual reports. Whilst, in United States, a study by Cho, Freedman and Patten (2012) indicated that the disclosure of environmental information is 84.5 percent. Thailand also shows the higher percentage of environmental disclosure which is 83 percent (Suttipun \& Stanton, 2012).

In Malaysia, the empirical study by Buniamin (2010) stated that only 28 percent of Malaysian companies disclosed their environmental activities in the annual reports for the financial year 2005. Similarly, a study by Bursa Malaysia (2008) based on 200 companies found that only nine percent received a good band and 4.5 percent received a leading band for their corporate social responsibility disclosure in their operations during the financial year of 2006 to 2007. Companies which received a leading band indicate that their corporate social and environmental reporting are closed to the international best practices benchmark. As for the environmental data, 25 percent of the companies received the zero score which indicates that the environmental activities are not the main concern among Malaysian companies.

A study by AlArussi and Selamat (2009) provided the evidence that general environmental consideration and statements are the most common disclosed items (51.5 percent) based on the Internet environmental disclosures among Malaysian listed companies. In addition, Iatridis (2013) found that only 54 percent of Malaysian companies gave the environmental information. A recent study by Bakar, Ghazali and Ahmad (2019) revealed that only 45.9 percent of Malaysian companies disclose information about the environmental activities. Therefore, Bursa Malaysia concluded that the corporate social responsibility awareness and reporting by most Malaysian public listed companies is lagging far behind the international best practice.

Nevertheless, the previous studies show that the level of social disclosure has increased given that the environmental reporting is quite new in Malaysia. However, most studies find that the environmental information disclosure is low compared to other themes of corporate social responsibility. In line with the above literature review, this study attempts to explore the current quality 
of environmental disclosure in Malaysia and whether the characteristics of the board of directors could increase such disclosure.

\section{Factors Affecting Environmental Disclosure Practices}

Environmental disclosure is also associated with many characteristics of the corporate governance and board members. For instance, the independent board members (Rao, Tilt \& Lester, 2012) in Australia have been found to significantly affecting the level of environmental disclosure. Consistent findings have also been shared in the studies by Johnson and Greening (1999), Chau and Gray (2010), and Fuente, Garcia-Sanchez and Lozano (2017). These studies justify that independent non-executive directors have strong impact on the general voluntary disclosure as well as specific CSR and environmental disclosures. The strong impact of independent directors on environmental disclosure may be justified in a number of reasons. Firstly, independent non-executive directors sitting on board are highly said to be enhancing the process of monitoring the management behavior (Cornett, Marcus \& Tehranian, 2008). Secondly, the non-executive directors add great value to company performance due to their independence from inside directors (Baysinger \& Butler, 1985) that lead to better acquisitions (Paul, 2007). They incline to pay more attention to the interests of all stakeholders because they are more responsive to social demands and thus motivate firms to be more engaged in sustainability (Ibrahim \& Angelidis, 1995).

Meanwhile, a research conducted in Malaysia reveals that an independent non-executive chairman also plays a significant role in affecting the level of environmental disclosure (Said, Omar \& Abdullah , 2013). Their findings justify the role of independent non-executive directors who are acting as a check and balance mechanism and play a monitoring role in performing and carrying out their governing functions, duties and decision making in an organisation. However, Haniffa and Cooke (2002) found a negative relationship between the non-executive directors and the voluntary social reporting disclosure. Furthermore, few studies recorded the non-significance of independent non-executive directors with voluntary disclosures (Abdullah, Mohamad \& Mokhtar, 2011). They further state that the nature of the independent non-executive directors in Malaysia may not be well conversant about the firms' operation, do not support the board's CEO, executive directors and majority shareholders but pursue the interest of the firms' minority shareholders and firms' stakeholders. The non-executive directors selected are also believed to be those in the same circle as the firms' CEO (Grady, 1999) whereby the focus is spent more on satisfying the expectation of majority shareholders compared to fulfilling the hope of stakeholders. The insignificant relationship of independent directors was also found in a study 
by Michelon and Parbonetti (2012). The authors believe that the relationship will only be significant if the independent directors selected have community influence that brings legitimacy to the firms. As a result, firms may be more adhere in reporting their environmental disclosure.

Another board characteristic that has been found to be positively influencing voluntary disclosure is the multiple directorships (Haniffa \& Cooke, 2005; Elsakit \& Worthington, 2014; Rao \& Tilt, 2016). However, these findings focus more on CSR disclosures, while the effect of multiple directorship on environmental disclosure remain scarce. Directors who have multiple directorships are said to have greater access of information which they obtained from a number of companies and are able to use such information to benefit the companies where they are directing (Hashim \& Abdul Rahman, 2011). As a result, these directors with multiple directorships will be more transparent (Ho \& Shun Wong, 2001), and are more likely to disclose information (Rupley et al, 2012; Razek, 2014), including the voluntary information such as the environmental disclosure. On the other hand, Harris and Shimizu (2004) argued that serving on multiple boards could reduce the available preparation time for board meetings and limit the directors' ability to provide useful advice.

Furthermore, the board members' background is also important in determining the environmental disclosure. Said et al. (2013) claimed that companies who have CEOs with law background tend to have greater environmental disclosure due to their understanding in the law that helps them to be more aware of the regulations and laws governing a company. The level of environmental disclosure is also found to be affected by the proportion of women in the corporate board (Rao et al., 2012). In addition, they state that female directors have more active involvement, better preparation, independence and other qualities that enable them to make significant contributions and decision making such as in the case of environmental disclosure.

Companies also disclose or report their environmental information as a result of institutionalism. In Spain, a research that focused on wind energy sector revealed that there is evidence that institutional pressures, categorised as coercive, normative and mimetic pressures, have impact on environmental reporting practice (Mosene, Burritt, Sanagustin, Monevan, Tingey-Holyoak, 2013). Coercive pressures are associated with following the industry leader in terms of engagement with sustainability indexes while mimetic pressures are linked with the tendency towards the adoption of third-party or external verification. Meanwhile, the items reported and the movement from one 
sustainability standards to another pictures the normative and mimetic pressures on the companies (Mosene et al., 2013).

\section{Hypotheses Development}

Mathews (1993) argued that legitimacy theory is related to the social contract concept whereby the society provides the resources to the corporation and in turn the corporation produces products, services and other benefits to the society. He further states that the corporation cannot survive if their actions do not conform to the expectations of the society. Legitimacy theory implies that the corporation will ensure their operation and achievement will be accepted by the society (Wilmshurst \& Frost, 2000). When the corporation's activities have a negative effect on the environment, they have to disclose additional information to society. A study by Deegan, Rankin and Tobin (2002) shared that the annual report is a tool used by the management to legitimise their activities by disclosing a large amount of information in the annual report for certain issues that may have attracted the media.

Freedman and Jaggi (2005) asserted that corporation which discloses more additional information to provide views about their companies could assist external users in making their own decisions. According to the agency theory, the board of directors can reduce the agency conflict between the management and the owner by providing more additional information (Fama \& Jensen, 1983; Fama, 1980; Jensen \& Meckling, 1976) such as environmental disclosure. Based on the previous studies, the board of director characteristics which are examined in this study comprise board size, board meetings, non-executive directors, multiple directorships, female directors and Muslim directors. Underpinning by legitimacy and the agency theory, the board of director characteristics are expected to influence the disclosure of additional information (i.e., environmental disclosure) in the annual reports.

\section{Board Size}

Fama and Jensen (1983) argued that the total number of directors in a company's board may affect the approach taken by the directors to perform their responsibilities. The agency theory argues that the directors will reduce the asymmetry problem the between management and shareholders (Birnbaum, 1984; Chen \& Jaggi, 2000). Therefore, it is suggested that the quality of environmental disclosure is higher in a company that has a larger board size. Based on the above discussion, the first hypothesis is: 
$\mathrm{H}_{1}$ There is a positive association between the board size and the disclosure of environmental information.

\section{Board Meetings}

More board meetings can increase the performance of company since many activities can be planned and more issues can be resolved during board meetings (Nkundabanyanga, Ahiauzu, Sejjaaka \& Ntayi, 2013). Their argument is based on the agency theory that more board meetings which are organised properly can increase communication of information as they have more time to discuss the issues related to additional information such as environmental activities and disclosure. Accordingly, it is thus hypothesised:

$\mathrm{H}_{2}$ There is a positive association between the number of board meeting and the disclosure of environmental information.

\section{Non-executive Directors}

Pfeffer and Salancik (2003) suggest that one of the strategies to deal with an organization's relationships with their environment is by the selection of outside directors. Outside directors can help firms to maintain their legitimacy and enhance the reputation and credibility of a firm by providing more social and environmental activities (Ajibolade \& Uwuigbe, 2013). Johnson and Greening (1999) also mentioned that outside directors will encourage the firms to comply with the environmental standards to avoid penalties, fines, negative media exposure and a subsequent loss of reputation. Furthermore, Zahra and Stanton (1988) argued that the disclosure of social and environmental information will reflect the responsibility and integrity of the non-executive directors. Based on the agency theory, the non-executive directors will lead to a good monitoring process, and in turn, it can reduce the agency's conflicts (Fama \& Jensen, 1983) by encouraging companies to provide more information about environmental activities conducted by the companies. As such, previous findings justify a positive relationship between the independent non-executive directors with the general voluntary disclosure as well as the specific CSR and environmental disclosures (Johnson \& Greening, 1999; Chau \& Gray, 2010). Based on the foregoing discussion, it is thus hypothesised that:

$\mathrm{H}_{3}$ There is a positive association between the proportion of non-executive directors and the disclosure of environmental information. 


\section{Multiple Directorships}

Multiple directorship means that directors in certain company also sit in the board of director of the other company. According to Dahya, Lonie and Power (1996), instead of making information more transparent, multiple directorships can also help directors to understand the issues related to corporate social disclosure. These experiences are gained through exposure to several companies in the same industry or different industry. Therefore, boards with multiple directorships could suggest the management to implement more environmental activities and disclose those activities to mitigate the agency costs. Madi, Ishak and Manaf (2014) suggested that multiple directorships increase the monitoring role which lead to enhance the disclosure of additional information by companies. Studies by Haniffa and Cooke (2005), Elsakit and Worthington (2014) and Rao and Tilt (2016) revealed a positive significant relationship between voluntary disclosure and multiple directorships. Therefore, it is hypothesised that:

$\mathrm{H}_{4}$ There is a positive association between the multiple directorships and the disclosure of environment information.

\section{Female Directors}

Female directors are more likely to monitor and consult the management team using their new leadership styles which can increase the effectiveness of the boards and companies performance (Adams \& Ferreira, 2007; Bertrand \& Schoar, 2003). The existence of female directors could enhance the communication of information because they have certain quality of attitudes that attempt to improve their relationships with the stakeholders (Shrader, Blackburn \& Iles, 1997). In addition, Barako and Brown (2008) indicated that female directors are more likely to show their good corporate citizens by promoting social responsible activities implemented by companies. The increased disclosure suggested by female directors could reduce the information asymmetry between management and shareholders. Empirical study by Upadhyay and Zeng (2014) found that diversity of the board enhances the information collected by managers who will communicate that information to the financial analysts. In the same vein, Fernandez-Feijoo, Romero and Ruiz (2012) and Liao, Luo and Tang (2014) proved that more women on boards have increased the disclosure of voluntary information about social and environmental activities. Based on the above argument, the following hypothesis is stated as follows:

$\mathrm{H}_{5}$ There is a positive relationship between the female director and the disclosure of environmental information. 


\section{Muslim Directors}

Rahman (2003) argued that the board of directors could influence the management to communicate more voluntary information to show their responsibilities to the owner and community. This is consistent with the concept of accountability in Islam that promotes the concept of full disclosure of information (Baydoun \& Willett, 2000) beyond that is required by the regulation. Anuar, Sulaiman and Nik Ahmad (2009) revealed that Muslim directors can increase the reporting of information due to their excessive experience in Islamic concept including the approach on how to conduct the business activity in an ethical way. Reporting the socio-economic activities regarding social and environmental information is one way to discharge Islamic accountability (Rizal \& Hameed, 2005), to increase the companies' legitimacy and to reduce the agency conflict. The study by Abd-Mutalib, Yahya and Taib (2015) revealed a positive relationship between Muslim directors and corporate social reporting. Hence, it is expected that the proportion of Muslim directors on the board will influence the reporting of environmental information.

$\mathrm{H}_{6}$ There is a positive relationship between the proportion of Muslim directors on board and the disclosure of environmental information.

\section{Methodology}

\section{Sample Selection and Sources of Information}

Data were collected from 2016 annual report of the public listed companies on the Main Market of Bursa Malaysia excluding the banks and financial institutions' companies. Year 2016 was chosen based on the latest available data when the study was conducted. The sample of this study consists of 353 companies randomly selected from various industries including industrial product, trading/services, technology, consumer product, properties, construction and plantation.

Annual reports are used as a source of document for data collection because the annual report are regarded as important documents in the corporate social responsibility due to the high degree of credibility of information reported within them (Tilt,1994). Annual reports are also used by a number of stakeholders as the source of certain information such as the environmental activities and their widespread distribution (Deegan \& Rankin, 1997). Annual reports are also produced regularly in Malaysia as required by the Bursa Malaysia Listing requirement. 


\section{Model of the Study and Measurement of Variables}

To investigate whether the characteristics of board of directors influence the disclosure of environmental information, the following model is used:

$$
\begin{aligned}
& \text { ED }_{\mathrm{j}}=\beta_{0}+\beta_{1} \text { BSIZE }_{\mathrm{j}}+\beta_{2} \text { BMEET }_{\mathrm{j}}+\beta_{3} \text { NONEXEC }_{\mathrm{j}}+\beta_{4} \text { MULTID }_{\mathrm{j}}+ \\
& \beta_{5} \text { FEMALE }_{\mathrm{j}}+\beta_{6} \text { MUSLIM }_{\mathrm{j}}+\beta_{7} \text { SIZE }_{\mathrm{j}}+\beta_{8} \text { ROA }_{\mathrm{j}}+\mathrm{e}_{\mathrm{i}}
\end{aligned}
$$

Where ED is environmental disclosure score, BSIZE is board size, BMEET is board meeting, NONEXEC is non-executive director, MULTID is multiple directorship, FEMALE is female director, MUSLIM is Muslim director, SIZE is size of company, ROA is profitability.

The dependent variable (ED) is the total quality score of environmental disclosure based on environmental index. The index of environmental disclosure is based on the index used by Abd-Mutalib, Jamil and WanHussin (2014). This index is appropriate for small and big companies as this index has been used by previous Malaysian studies such as Saleh, Zulkifli and Muhamad (2010), Bursa Malaysia (2008) and Amran and Devi (2007). The index consists of nine items namely Effective Usage of Energy and Resources, Waste Management and Disposal, Reusing and Recycling, Pollution and Emission Control, Environmental Conservation, Environmental Campaign, Environmental Policy, Certification and Awards Achievement, and Prevention and Reparation Programme.

The independent variables are measured as follow. BSIZE is measured based on the total number of directors on the board (Akhtarudin, Hossain, Hossain \& Yao, 2009). BMEET is the number of board meeting held in the year (Vafeas, 2013). NONEXEC is the percentage of non-executive directors to total boards (Weir \& Lang, 2001). MULTID is based on the proportion of directors that also sit in the board of director of the other company (Haniffa \& Cooke, 2005). FEMALE is the proportion of female directors to the total directors on the board (Liao et al. 2014) and proportion of Muslim directors on the board for MUSLIM variable (Abd-Mutalib et al, 2015). For control variables, SIZE is proxied by natural log of total assets (Amran \& Che Ahmad, 2010) and ROA is measured by using return on assets (net income divided by total assets) (Ahmad,Hassan \& Mohammad, 2003).

Several methods of data analysis are used to answer the research questions of the study. Descriptive statistics is used to explain the minimum, maximum, mean and the median of independent variables. Correlation 
analysis is conducted to illustrate the relationship between the two variables. Linear regression is used to test the relationship between the environmental disclosure and the board director characteristics.

\section{Findings and Discussion}

\section{Descriptive Statistic of Environmental Information}

This study explores the disclosure of nine items of environmental information in the annual reports. The content analysis of 353 annual reports shows that Malaysian companies do not disclose all nine items of the environmental information investigated in this study. The result in Table 1 shows that the most disclosed item is the effective usage of energy and resources (49.6\%). Then it is followed by the waste management and disposal (47.3\%), pollution and emission control (38.2\%) and reusing and recycling (38.2\%). The least disclosed item of the environmental information by Malaysian companies is the prevention and reparation programme (12.7\%).

\section{Table 1}

The Disclosure of Environmental Information

\begin{tabular}{lcc}
\hline \multicolumn{1}{c}{ Environmental information } & $\begin{array}{c}\text { Number of } \\
\text { companies } \\
\text { disclosed }\end{array}$ & $\begin{array}{c}\text { Percentage of } \\
\text { companies disclosed } \\
(\%)\end{array}$ \\
\hline Effective usage of energy and resources & 175 & 49.6 \\
Waste management and disposal & 167 & 47.3 \\
Reusing and recycling & 135 & 38.2 \\
Pollution and emission control & 135 & 38.2 \\
Environmental conservation & 100 & 28.3 \\
Environmental campaign & 99 & 28 \\
Environmental policy & 96 & 27.2 \\
Certification and awards achievement & 82 & 23.2 \\
Prevention and reparation programme & 45 & 12.7 \\
\hline
\end{tabular}

\section{Descriptive Statistic of Independent Variables}

Table 2 presents the descriptive statistics of this study by showing the information about the minimum, maximum, mean and standard deviation for independent variables. The descriptive statistics of independent variables show that the average of board size (BSIZE) is 7.3343, the minimum number 
of board is four and the maximum is 16 . This number is the maximum number of board size as suggested by the Companies Act (2016) which is 14 . As for the board meeting (BMEET), the average is 5.4873 with the minimum of meeting at least once a year, and the maximum board meeting at 17 times yearly. These findings indicate that companies with minimum of one board meeting are unlikely to have complied with the requirement of company constitution which requires the board to meet at least six time in a year. The average of non-executive director (NONEXEC) is 0.6605 with the maximum being one. As for the multiple directorships (MULTID), the minimum is zero, the maximum is one, and the average is 0.5101 . The results show that Malaysian companies have less female directors (FEMALE), with an average of only 0.1103 . The minimum and maximum of female directors is 0 and 0.63 respectively. Similarly, results in Table 2 show that Muslim directors (MUSLIM) have a maximum of one with the average being only 0.2975 . For the size of companies (SIZE) and profitability (ROA), the average is 13.0588 and 3.9240 respectively.

Table 2

Descriptive Statistics of Independent Variables

\begin{tabular}{lcccc}
\hline & Minimum & Maximum & Mean & Std. Deviation \\
\hline ED & 0.00 & 1.00 & 0.3255 & 0.2708 \\
BSIZE & 4.00 & 16.00 & 7.3343 & 1.8788 \\
BMEET & 1.00 & 17.00 & 5.4873 & 1.8186 \\
NONEXEC & 0.30 & 1.00 & 0.6605 & 0.1853 \\
MULTID & 0.00 & 1.00 & 0.5101 & 0.2985 \\
FEMALE & 0.00 & 0.63 & 0.1103 & 0.1239 \\
MUSLIM & 0.00 & 1.00 & 0.2975 & 0.2684 \\
SIZE & 9.39 & 17.84 & 13.0588 & 1.4667 \\
ROA & -37.64 & 57.35 & 3.9240 & 7.7991 \\
\hline
\end{tabular}

\section{Correlation Analysis and Multicollinearity Test}

The present study shows the result of correlation analysis and multicollinearity test before presenting the result of multiple regression that shows the relationship between the aforementioned dependent variable and independent variables. Correlation analysis is conducted to examine the relationship between two variables. Table 3 presents the Pearson correlation between independent variables tested in this study. The results show a strongly weak 
relationship between all variables involved in this study as all the correlations are less than 0.5 . The significant positive correlation between NONEXEC and BMEET (0.228) indicates that companies with more non-executive directors are more likely to have a higher number of board meeting. However, board meeting and environmental disclosure (ED) are not correlated. ED has positive correlation with SIZE (0.416), BSIZE (0.124), NONEXEC (0.167) and MULTID (0.206). Similarly, positive significant correlation can be seen between MUSLIM and BMEET (0.176). It shows that higher Muslim directors on the board will lead to more board meetings. MUSLIM also has a significant positive relationship with NONEXEC (0.297) and MULTID (0.211). It shows that the companies with more Muslim directors are more likely to have greater non-executive directors and their directors also have multiple directorships in other companies. In addition, MUSLIM and SIZE also have a significant positive correlation $(0.226)$. On the other hand, a negative significant relationship can be seen between ROA and BMEET $(-0.140)$. This result specifies that less profitable companies will have more board meetings.

Table 3

Correlation Analysis

\begin{tabular}{lccccccccc}
\hline & ED & BSIZE & BMEET & $\begin{array}{c}\text { NON- } \\
\text { EXEC }\end{array}$ & MULTID & FEMALE & MUSLIM & SIZE & ROA \\
\hline ED & 1.000 & & & & & & & & \\
BSIZE & $0.124 *$ & 1.000 & & & & & & & \\
BMEET & 0.036 & 0.078 & 1.000 & & & & & & \\
NONEXEC & $0.167 * *$ & -0.091 & $0.228 * *$ & 1.000 & & & & & \\
MULTID & $0.206 * *$ & 0.058 & 0.074 & $0.240^{* *}$ & 1.000 & & & & \\
FEMALE & 0.031 & 0.041 & 0.082 & 0.060 & -0.054 & 1.000 & & & \\
MUSLIM & 0.102 & 0.041 & $0.176^{* * *}$ & $0.297 * *$ & $0.211^{* *}$ & 0.029 & 1.000 & & \\
SIZE & $0.416 * *$ & $0.341 * *$ & 0.103 & $0.167 * *$ & $0.274 * *$ & 0.061 & $0.226 * *$ & 1.000 & \\
ROA & 0.037 & 0.034 & $-0.140^{* *}$ & -0.038 & $-0.132 *$ & $0.121 *$ & -0.056 & 0.069 & 1.000 \\
\hline Note: * and * $*$ indicate significant at 10 percent and 5 percent level, respectively
\end{tabular}

Table 4 presents the result of the Collinearity Diagnostic Test to further investigates the existence of multicollinearity problem in the model. The results show that the variance inflation factor for all independent variables is less than 10. Additionally, the tolerance value for all independent variables also is more than 0.10 . Therefore, the result of this test proved that the multicollinearity problem does not exist in the model. 
Table 4

Multicollinearity Test

\begin{tabular}{lcc}
\hline \multirow{2}{*}{ Variable } & Tolerance & Collinearity statistics \\
\hline BSIZE & 0.854 & VIF \\
BMEET & 0.903 & 1.170 \\
NONEXEC & 0.821 & 1.108 \\
MULTID & 0.853 & 1.217 \\
FEMALE & 0.967 & 1.173 \\
MUSLIM & 0.859 & 1.034 \\
SIZE & 0.771 & 1.165 \\
ROA & 0.936 & 1.297 \\
\hline
\end{tabular}

\section{Regression Analysis}

This section discusses the result of multiple regression analysis that is used to test the relationship between the dependent and independent variables. The dependent variable in this study is environmental disclosure (ED). The independent variables are board size (BSIZE), board meeting (BMEET), nonexecutive director (NONEXEC), multiple directorship (MULTID), female director (FEMALE) and Muslim director (MUSLIM). Control variables used in this study are the size of company (SIZE) and profitability (ROA). The results of multiple regression in Table 6 shows that the adjusted $R^{2}$ is 0.172 . The results indicate that six independent variables and two control variables can only explain 17.2 percent of the variation in the dependent variable, which is environmental disclosure.

The multiple regression results in Table 5 indicate that only non-executive (NONEXEC), multiple directorship (MULTID) and size of company (SIZE) have a significant relationship with environmental disclosure (ED). Nonexecutive director and multiple directorship have a positive significant relationship with environmental disclosure at 10 percent level. However, the size of companies has a positive relationship with environmental disclosure at 1 percent significant level. The results of this study presumes that more non-executive board of directors are more likely to influence the companies to disclose more environmental information. Non-executive directors and multiple directorships seem to increase environmental disclosures (ED) due to their reputation, experience and governance skills given to companies. The results of this study is consistent with Chau and Gray (2010) and Fuente 
et al. (2017). Similarly, the directors who also sit as the board of director of the other companies are likely to be motivated to report more information related to the environmental activities implemented by their companies. Studies by Elsakit and Worthington (2014) and Rao and Tilt (2016) also found that multiple directorships could influence the disclosure of voluntary information.

Other variables namely board size (BSIZE), board meeting (BMEET), female director (FEMALE), Muslim director (MUSLIM) and profitability (ROA) have no significant relationship with the environmental disclosure. These results indicate that these variables will not influence the disclosure of environmental information in the annual report of Malaysian companies.

Table 5

Regression Analysis Results

\begin{tabular}{lcccc}
\hline Variables & Coefficients & Std. Error & t-value & Sig. \\
\hline (Constant) & -.698 & .126 & -5.557 & .000 \\
BSIZE & .000 & .008 & -.028 & .978 \\
BMEET & -.004 & .008 & -.490 & .625 \\
NONEXEC & .128 & .072 & 1.780 & $.076^{*}$ \\
MULTID & .080 & .048 & 1.688 & $.092^{*}$ \\
FEMALE & .016 & .108 & .151 & .880 \\
MUSLIM & -.026 & .053 & -.496 & .620 \\
SIZE & .071 & .010 & 6.937 & $.000^{* * *}$ \\
ROA & .001 & .002 & .397 & .692 \\
R-squared & & & 0.191 & \\
Adj. R-squared & & & 0.172 & \\
Std. Error of the Estimate & & & 0.24643 & \\
\hline
\end{tabular}

Note: * and *** indicate significant at 10 percent and 1 percent level, respectively

\section{Conclusion and Future Research}

This study attempts to examine the current practices of environmental disclosure by Malaysian listed companies. The content analysis of annual reports of 353 companies from various industries in Malaysia shows that most of them disclose some forms of environmental information in their annual report for the year 2016. Information about effective usage of energy 
and resources is the highest item disclosed by Malaysian companies. Then it is followed by waste management and disposal and, reusing and recycling information. The least item disclosed by Malaysian companies is prevention and reparation program.

The regression results provide evidence that the higher proportion of non-executive directors could increase the disclosure of environmental information. The results prove that non-executive directors have played their role to increase the companies' legitimacy by encouraging the management of companies to provide more environmental information as suggested by Ajibolade and Uwuigbe (2013). In addition, Malaysian code of corporate governance has suggested that Malaysian companies should have more non-executive directors to monitor the management. More social and environmental information will be disclosed by companies that have more non-executive directors on the boards because they are not only focus on shareholders but also are more concern to satisfy the demand of voluntary information by various stakeholder (Ibrahim \& Angelidis, 1995). Descriptive statistics of this study show that average non-executive directors in the sample is 0.6502 . It also shows that most of Malaysian companies have more non-executive directors in their companies to advice the management to implement and report information related to environmental activities. More information about environmental activities could assist the external users to make a various decision and to avoid penalties given to companies that not comply with environmental regulation.

This study also provides evidence that multiple directorship could influence the disclosure of environmental information. It shows that the directors who also sit in the board of director of other company could use their knowledge and experience from various companies whether in similar of different industry to assist the management to deal with the issues of environmental activities and disclosures.

This study is motivated by the importance of environmental activities implemented by Malaysian companies to ensure limited resources are still available not only for human beings but also for flora and fauna. The communication of environmental activities by Malaysian companies in the annual report shows the transparency of companies towards the sustainability of resources for future generation. Hence, the findings of this study provide significant contribution for supervisory bodies and policy makers in developing guidelines for Malaysian companies that are concerned with the environmental issues through environmental disclosures in their annual reports. 
Although Malaysian companies are actively done an effort to save energy and resources, the activities related to prevention and reparation program are still lacking. Limited companies voluntarily take preventive activities to protect the destruction of natural environment because of their business activities. Furthermore, some companies are reluctant to do additional improvement to safeguard the natural habitats, air and water surrounding the location of their activities. In order to provide a good quality of life for the next generation, it is hoped that Malaysian regulator and government will encourage companies to consider environmental activities as a part of their sustainability program and communicate the activities to their stakeholders. Lastly, Malaysian government should provide a reward to companies that are actively involved in the environmental activities to encourage them to continue the activities in the long run.

However, this study has several limitations due to only one year data that is based on the annual report of 2016. Future study could be extended to look into several years in order to examine the trend of environmental disclosure by Malaysian companies. The second limitation is related to the board characteristics variables in this study which are less comprehensive and resulted in the low adjusted $\mathrm{R}^{2}$. The future research is suggested to include other corporate governance characteristics that may influence the disclosure of environmental information in the annual report of Malaysian companies.

\section{Acknowledgements}

This work was supported by the Geran Penjanaan, Universiti Utara Malaysia, 2017.

\section{References}

Abd-Mutalib, H., Muhammad Jamil, C. Z., \& Wan Hussin, W. N. (2014). The availability, extent and quality of sustainability reporting by Malaysian listed firms: Subsequent to mandatory disclosure. Asian Journal of Finance \& Accounting, 6(2), 239-257.

Abd-Mutalib, H., Yahya, N. H., \& Taib, S. (2015). Muslim board of directors and corporate social responsibility reporting: Evidence from Malaysia. Advanced Journal of Technical and Vocational Education, 1(2), 115-123.

Abdullah, S. N., Mohamad, N. R., \& Mokhtar, M. Z. (2011). Board independence, ownership and CSR of Malaysian large firms. Corporate Ownership and Control, 8(3), 68-82. 
ACCA (2003). Environmental reporting guidelines for Malaysia Companies. Certified Accountants Educational Trust, London.

Adams, R., \& Ferreira, D. (2009). Women in the boardroom and their impact on governance and performance. Journal of Financial Economics, 94, 291-309.

Ahmad, Z., Hassan, S., \& Mohammad, J. (2003). Determinants of environmental reporting in Malaysia. International Journal of Business Studies, 11(1), 69-90.

Akhtaruddin, M., Hossain, M. A., Hossain, M., \& Yao, L. (2009). Corporate governance and voluntary disclosure in corporate annual reports of Malaysian listed firms. JAMAR, 7(1), 1-20.

Ajibolade, S. O., \& Uwuigbe, U. (2013). Effects of corporate governance on corporate social and environmental disclosure among listed firms in Nigeria. European Journal of Business and Social Sciences, 2(5), 76-92.

AlArussi, A. S., \& Selamat, M. H. (2009). Dominant personalities in board committees, company characteristics, and internet environmental disclosure by Malaysian listed companies. Malaysian Management Journal, 13(1\&2), 51-67.

Amran, N. A., \& Che Ahmad, A. (2010). Family succession and firm performance among Malaysian companies. International Journal of Business and Social Science, 1(2), 193-203.

Amran, A., \& Devi, S. S. (2007). Corporate social reporting in Malaysia: A political theory perspective. Management Accounting Review, 6(1), $18-44$.

Anuar, H.A., Sulaiman, M., \& Nik Ahmad, N. N. (2009). Some evidence of environmental reporting by shariah compliance companies in Malaysia. IIUM Journal of Economic and Management, 17(2), 177205.

Bakar, A. B.S. A., Ghazali, N. A. B. M., \& Ahmad, M. B. (2019). Sustainability reporting in Malaysia: The extent and quality. International Journal of Academic Research in Business and Social Sciences, 9(5), 816835.

Barako, D. G., \& Brown, A. M. (2008). Coprporate social reporting and board repreentation: Evidence frpm the Kenyan banking sector. Journal of management and Governance, 12(4), 309-324.

Baydoun, N., \& Willet, R. (2000). Islamic corporate reports. Abacus, 36 (1), 71-90.

Baysinger, B., \& Butler, H. (1985). Corporate governance and the board of directors: Performance effects of changes in board composition. Journal of Law, Economics, and Organizations, 1, 101-124.

Bertrand, M. A., \& Schoar, A. (2003). Managing with style: The effect of managers on firm policies. Quarterly Journal of Economics, 118(4), 1169-1208. 
Birnbaum, P. H. (1984). The choice of strategic alternatives under increasing regulation in high technology companies. Academy of Management Journal, 27(3), 489-510.

Buniamin, S. (2010). The quantity and quality of environmental reporting in annual report of public listed companies in Malaysia. Issues in Social and Environmental Accounting, 4(2), 115-135.

Bursa Malaysia. (2018, 27 December). Sustainable reporting guide. Retrieved from http://www.bursamalaysia.com.

Bursa Malaysia. (2015, 27 December). Sustainable reporting guide. Retrieved from http://www.bursamalaysia.com.

Bursa Malaysia. (2008, 27 March). CSR: 2007 status report. Retrieved from http://www.bursamalaysia.com.

Bursa Malaysia. (2010, 10 October). Main market listing requirement. Retrieved from http://www.bursamalaysia.com/website/bm/ regulation/rule/listing requirements.

Chau, G., \& Gray, S. J. (2010). Family ownership, board independence and voluntary disclosure: Evidence from Hong Kong. Journal of International Accounting, Auditing and Taxation, 19(2), 93-109.

Cho, C. H., Freedman, M., \& Patten, D. M. (2012). Corporate disclosure of environmental capital expenditures A test of alternative theories. Accounting, Auditing \& Accountability Journal, 25(3), 486-507.

Chen, C. J. P., \& Jaggi, B. (2000). Association between independent nonexecutive directors, family control and financial disclosures in Hong Kong. Journal of Accounting and Public Policy, 19, 285-310.

Cormier, D., \& Magnan, M. (1999). Corporate environmental disclosure strategies: Determinants, costs and benefits. Journal of Accounting, Auditing and Finance, 14(4), 429-452.

Cornett, M. M., Marcus, A. J., \& Tehranian, H. (2008). Corporate governance and pay-for-performance: The impact of earnings management. Journal of Financial Economics, 87(2), 357-373.

Dahya, J., Lonie, A. A., \& Power, D. M. (1996). The case for separating the roles of chairman and CEO: An analysis of stock market and accounting data. Corporate Governance: An International Review, $4(2), 71-77$.

Deegan, C., \& Rankin, M. (1997). The materiality of environmental information to users of annual reports. Accounting, Auditing and Accountability Journal, 7(4), 94-109.

Deegan, C., Rankin, M., \& Tobin, J. (2002). An examination of the corporate social and environmental disclosures of BHP from 1983-1997. Accounting, Auditing \& Accountability Journal, 15(3), 312-343. 
Elsakit, O. M., \& Worthington, A. C. (2014). The impact of corporate characteristics and corporate governance on corporate social and environmental disclosure: A literature review. International Journal of Business and Management, 9(9), 1-15.

Fama, E. F. (1980). Agency problems and the theory of the firm. Journal of Political Economy, 88(2), 288-307.

Fama, E. F., \& Jensen, M. C. (1983). Separation of ownership and control. Journal of Law and Economics, 26(2), 301-325.

Freedman, M., \& Jaggi, B. (2005). Global warming, commitment to the Kyoto protocol, and accounting disclosures by the largest global public firms from polluting industries. The International Journal of Accounting, 40(3), 215-232.

Fernandez-Feijoo, B., Romero, S., \& Ruiz, S. (2012). Does board gender composition affect corporate social reaponsibility reporting? International Journal of Business and Social Science, 3(1), 31-38.

Fuente, J. A., García-Sánchez, I. M., \& Lozano, M. B. (2017). The role of the board of directors in the adoption of GRI guidelines for the disclosure of CSR information. Journal of Cleaner Production, 141, 737-750.

Grady, D. (1999). No more board games. The McKinsey Quarterly, 3, 17-25. Hackston, D., \& Milne, M. J. (1996). Some determinants of social and environmental disclosure in New Zealand companies. Accounting, Auditing and Accountability Journal, 9 (1), 77-108.

Halme, M., \& Huse, M. (1997). The influence of corporate governance, industry and country factors on environmental reporting. Scandinavian Journal of Management, 13(2), 137-157.

Haniffa, R. M., \& Cooke, T. E (2002). Culture, corporate governance and disclosure in Malaysian corporation. Abacus, 38, 317-349.

Haniffa, R. M., \& Cooke, T. (2005). The impact of culture and governance on corporate social reporting. Journal of Accounting and Public Policy, 24(5), 391-430.

Hashim, U. J., \& Abdul Rahman, R. (2011). Board independence, board diligence, board expertise and impact on audit report lag in Malaysian market. Paper presented at Finance and Corporate Governance Conference.

Ho, S. S. M., \& Shun Wong, K. (2001). A study of the relationship between corporate governance structures and the extent of voluntary disclosure. Journal of International Accounting, Auditing and Taxation, 10(2), 139-56.

Ibrahim, N. A., \& Angelidis, J. P. (1995). The corporate social responsiveness orientation of board members: Are there differences between inside and outside directors? Journal of Business Ethics 14(5), 405-419 
Jensen, M. C., \& Meckling, W. H. (1976). Theory of the firm: Managerial behavior, agency costs and ownership structure. Journal of Financial Economics, 3(4), 305-360.

Johnson, R. A., \& Greening, D. W. (1999). The effects of corporate governance and institutional ownership types on corporate social performance. Academy of Management Journal, 42(5), 564-576.

Iatridis, G. E. (2013). Environmental disclosure quality: Evidence on environmental performance, corporate governance and value relevance. Emerging Markets Review, 14, 55-75.

Liao, L., Luo, L., \& Tang, Q. (2014). Gender diversity, board independence, environmental committee and greenhouse gas disclosure. The British Accounting Review, 1-16.

Madi, H. K., Ishak, Z., \& Manaf, N. A. A. (2014). The impact of audit committee characteristics on corporate voluntary dislosure. Procedure - Social and Behavioural Sciences, 164, 486-492.

Mathews, M. R. (1993). Socially responsible accounting. London: Chapman Hall.

Michelon, G., \& Parbonetti, A. (2012). The effect of corporate governance on sustainability disclosure. Journal of Management \& Governance, $16,477-509$.

Mobus, J. L. (2005). Mandatory environmental disclosures in a legitimacy theory context. Accounting, Auditing and Accountability Journal, 18(4), 492-517.

Moerman, L., \& Laan, S. V. D. (2005). Social reporting in the tobacco industry: all smoke and mirrors? Accounting, Auditing and Accountability Journal, 18(3), 374-389.

Mosene, J. A., Burritt, R. L., Sanagustin, M. V., Moneva, J. M., \& TingeyHolyoak, J. (2013). Environmental reporting in the Spanish wind energy sector: an institutional view. Journal of Cleaner Production, 40, 199-211.

Nkundabanyanga, A., Ahiauzu, A., Sejjaaka, S. K., \& Ntayi, J. M. (2013). A model for effective board governance in Uganda's services sector firms. Journal of Accounting in Emerging Economies, 3(2), 125-144.

Paul, D. L. (2007). Board composition and corrective action: Evidence from corporate responses to bad acquisition bids. Journal of Financial and Quantitative Analysis, 42, 759-784

Pfeffer, J., \& Salancik, G. (2003). The external control of organisations: A resource dependence perspective. Stanford: Stanford University Press.

Rahman, A. A. R. (2003). Accounting regulatory issues on investments in Islamic Bonds. International Journal of Islamic Financial Services, 4(4). 
Rao, K., \& Tilt, C. (2016). Board diversity and CSR reporting: An Australian study. Meditari Accountancy Research, 24(2), 182-210.

Rao, K. K., Tilt, C. A., \& Lester, L. H. (2012). Corporate governance and environmental reporting: An Australian study. Corporate Governance, 12(2), 143-163.

Razek, M. A. (2014). The association between corporate social responsibility disclosure and corporate governance-A survey of egypt. Research Journal of Finance and Accounting, 5(1), 93-98.

Rizal, Y., \& Hameed, S. M. I. (2005). Objectives and characteristics of Islamic accounting for Islamic business organization. Malaysian Accounting Review, 4(1), 74-92.

Rupley, K. H., Brown, D., \& Marshall, R. S. (2012). Governance, media and the quality of environmental disclosure. Journal of Accounting and Public Policy, 31(6), 610-640.

Said, R., Omar, N., \& Abdullah, W. N. (2013). Empirical investigations on boards, business characteristics, human capital and environmental reporting. Social Responsibility Journal, 9(4).

Salama, A., Dixon, R., \& Habbash, M. (2012). An examination of environmental disclosures in UK corporate annual reports. Journal of Accounting Business and Management, 19(1), 19-42.

Saleh, M., Zulkifli, N., \& Muhamad, R. (2010). Corporate social responsibility disclosure and its relation on institutional ownership: Evidence from public listed companies in Malaysia. Managerial Auditing Journal, 25, 591-613.

Securities Commission Malaysia (2012, December 20). Malaysian code of corporate governance 2012. Retrieved from_http://www.sc.com.my

Shah, A. (2015). Radiation poisoning. New Straits Times. August, 3.

Shell (2014). Shell sustainability report. Royal Dutch Shell, Netherlands.

Shrader, C. B., Blackburn, V. B., \& Iles, P. (2003). Women in management and firm performance? A panel study of 2,300 Danish firms. Journal of Management Issues, 9(3), 355-372.

Suttipun, M., \& Stanton, P. (2012). Determinants of environmental disclosure in Thai corporate annual reports. International Journal of Accounting and Financial Reporting, 2(1), 99-115.

Tilt, C. A. (1994). The influence of external pressure groups on corporate social disclosure. Accounting, Auditing and Accountability Journal, 7(4), 47-72.

Trotman, K. T. (1979). Social responsibility disclosures by Australian companies. Chartered Accountants in Australia, 18(3), 47-69.

Upadhyay, A., \& Zeng, H. (2014). Gender and ethnic diversity on boards and corporate information environment. Journal of Business, 6 (7), 24562463. 
Weir, C., \& Lang, D. (2001). Governance structures, director independence and corporate performance in the UK. European Business Review, 13(2), 86-94.

Wilmshurst, T. D., \& Frost, G. F. (2000).Corporate environmental reporting: A test of legitimacy theory. Accounting, Auditing and Accountability Journal, 13(1).

Zahra, S. A., \& Stanton, W. W. (1988). The implications of boards of directors' composition for corporate strategy and performance. International Journal of Management, 5(2), 229-236. 